\title{
Beyond the Dead End: Gikuyus and Englishes in Colonial and Postcolonial Debates on Language and Decolonizing (Kenya)
}

\author{
Inge Brinkman
}

Africa's linguistic landscape shows signs of important changes in direction. While colonial history remains a crucial factor in language policies on the continent, more recent historical formations - related to migration, global capitalism, and other factors - start influencing the developments, choices and futures. The increasingly important role of English in French-oriented countries like Rwanda, the DRC and Morocco (Northrup 2013; Plonski et al. 2013; Soussi 2020) and the teaching of Mandarin in school curricula as well as the rising number of Confucius Institutes on the continent testify to this (for example Wheeler 2013).

At the same time, the role of African languages is institutionalized in some contexts. The choice of South Africa for 11 official languages, while promoting and ensuring respect for all other languages used in the nation, is a case in point. Until 1996 only English, Afrikaans and Dutch had formal status, while now isiNdebele, isiXhosa, isiZulu, Sepedi, Sesotho, Setswana, siSwati, Tshivenda and Xitsonga are also official languages. We can also refer to the 2013 constitution of Zimbabwe with its adoption of 16 languages as official, among these Shona and Ndebele, together spoken by some 90 per cent of the population.

Of course, we cannot now know how these developments will influence the future of African literature. Will the 'colonial moment' (Roberts 1990) subside in importance in the debates, and a post-postcolonial criticism develop? Will people's interest in African-language literature shift direction as the status of at least some African languages alter? In a special issue on African-language literatures, Sara Marzagora (2015; see also other articles in the special issue) invites us to connect Afrophone literatures to ongoing debates in comparative literature, postcolonial studies, and world literature, instead of the often binary approach to Europhone and Afrophone literatures. Such a more nuanced approach may start with studying how people in the past imagined linguistic futures, and how linguistic innovation was evaluated by African intellectuals at the time.

(C) INGE BRINKMAN, 2022 | DOI:10.1163/9789004471641_019 


\section{Vignette 1}

The year: 1962.

The place: The prestigious Makerere University in Uganda.

The scene: A choice of African writers from various parts of the continent gathers to hold a conference, significantly entitled Conference of African Writers of English Expression. Among those attending are Chinua Achebe, Wole Soyinka, John Pepper Clark, Kofi Awoonor and other important writers from West Africa; Ezekiel Mphahlele, Bloke Modisane, Lewis Nkosi, and Dennis Brutus from South Africa; Langston Hughes from the United States; Okot p'Bitek, Robert Serumaga and students from Makerere University, such as Grace Ogot, Rebecca Njau and (then still) James Ngugi from East Africa.

Notably absent are not only francophone and lusophone authors from Africa, but also authors writing in African languages are not present. Even Amos Tutuola apparently does not master 'English expression' well enough to fit the criteria (for more on the reasons for his exclusion, see Lo Liyong 1969: 159-6o).

A year later, one of the participants in the conference, Obi Wali published his famous essay "The dead end of African literature" (Wali 1963). In it he held that literature written in the colonial languages should not be classified as African literature: only literature written in African languages would qualify for that label.

These events are usually taken as the start of the debate about language and African literature. Generally, the argument has been represented as one between the very famous Nigerian writer Chinua Achebe as opposed to the also very famous Kenyan writer Ngũgĩ wa Thiong'o.

Ngũgĩ largely agrees with Obi Wali. He views English as 'Europhone', an imperial, foreign language that was imposed on Africans during the colonial era. In his well-known essay Decolonising the mind, he adopts an interpretation in which the assumed harmony of his youth - when there had been linguistic unity - had been broken by colonial education in English (Ngũgĩ 1986: 11). The policy of imposition formed part of a deliberate programme to destroy African languages and cultures, and to colonize the minds of African peoples. According to Ngũgĩ (2018: 125), this colonial project did not end with decolonization: it was continued, and even "completed and normalized" in the postcolonial period.

Ngũgĩ is not a man of words alone: since the end of the 196os he has undertaken numerous actions in line with his thinking: as lecturer at the University 
of Nairobi he played a key role in changing the department of English into a department of literature. He left Christianity, changed his name from James Ngugi to Ngũgĩ wa Thiong'o, started a theatre project in Gikuyu in his home village Kamĩrĩithũ and, in his 1986 book Decolonising the mind, he bade farewell to English as a medium of his writing (Ngũgĩ 1986: xiv). He then wrote - among other books - the heftiest novel in Gikuyu ever, Mũrogi wa Kagogo ( 768 pages) (Ngũgĩ 2007).

Nigerian writer Chinua Achebe agreed with neither Obi Wali nor Ngũgĩ. He viewed African literature as consisting of ethnic literatures, written in the various indigenous languages of Africa, and of national literatures, written in "the language of the erstwhile colonial powers" (Achebe 1965: 27). English had been a colonial import, but so had the nation: "I have been given this language and I intend to use it" (Achebe 1965: 30), he laconically concluded. National and ethnic language literatures both have their place: "Theatricalities aside, the difference between Ngũgĩ and myself on the issue of indigenous or European languages for African writers is that while Ngũgĩ now believes that it is either/or, I have always thought that it was both" (Achebe 2009: 97).

These debates continue to engage African authors, like Wole Soyinka, Mazisi Kunene, Cheikh Aliou Ndao, Penina Muhando Mlama, Sahle Selassie - to mention a few - with a recent exchange in the Journal of African Cultural Studies: Ngũgĩ holding onto his position (Ngũgĩ 2018) and Nigerian Biodun Jeyifo maintaining that "English is an African language", adding "Ka Dupe!", a Yoruba expression of gratitude (Jeyifo 2018).

\section{Vignette 2}

The year: 1929.

The place: The Independent school in Gakarara, Central Kenya.

The scene: A young boy is standing on guard by the roadside. His task is to warn those inside the school in the event of a nearing school inspection party.

Why is he standing there? Inside the school, the pupils are engaged in learning English. As they are not yet in Standard V this is illegal: colonial law forbids any student to be taught English during the first four years of schooling.

Before 1929, English had been part of the curriculum, also for pupils beginning with their primary education. In 1929, however, the British government in Kenya ruled that Swahili should be taught instead, with English as a subject only starting after Standard Iv. 
This caused much resentment. Mostly, the crisis of 1929 in Central Kenya is termed the 'female circumcision controversy', to refer to missionary meddling in what were regarded as private family matters, but Derek Peterson (2004: 147) has argued it had better be termed the 'language policy controversy'. Learning Swahili, the language between settlers and their personnel, the language of the lower administration in the colony, was regarded as a mere waste of time: "The Swahili had never conquered the Gikuyu", organizers of the Independent schools insisted. They wanted English, 'the official language of the British empire', to be taught (Peterson 2004:147), and called in the notion of wĩathi, usually translated as 'independence', describing it as "doing one's work without someone lording over him" (constitution of the Kikuyu Independent School Association, cited in Peterson 2004: 143).

Despite the resentment and the occasional act of disobedience, most Independent schools in Central Kenya stuck to educational regulations, earning general praise from the colonial school inspectors. (For more on the case, see Peterson 2004: 102-12, 121-2, 147-8).

The second vignette obviously complicates the first. When colonized people fought to have English included in the school curriculum, were they simply mistaken, running towards a dead end? The people in the two vignettes share a profoundly future-oriented notion of their projects. In both cases, ideas about a linguistic future - in the educational and literary realm - were connected to more than functionalist possibilities for upward social mobility, as they included the notion of countering domination and inequality, and to strive for independent decision-making and agency. In such imaginings of a just future, the past often plays an important role. Yet, in the struggle to reach for it, it seems hard to imagine that in the past people may have had different aspirations or different opinions about how to reach the same goal. The past serves as an argument in debate and, as such, historical complexity is often hard to fit in.

In 1995, Karin Barber was already pointing out that "writing in English can be understood more richly if we abandon the picture of the colonial language as an all-enveloping blanket of repression, and the indigenous languages as stifled, silenced sites of muted authenticity and resistance" (Barber 1995: 25). Postcolonial theory, she argued, all too often reduces historical complexities by conceptualizing literary production in English and African languages in a 
decontextualized and isolated way (Adejunmobi 1999; Barber 1995; Barber and Furniss 2006).

Barber's critique remains pertinent; with Jeyifo (2018: 135-6) holding that "it was Fanon who first theorized that all colonizers in the modern period act exactly the same way in imposing their languages, cultures and values on peoples and nations they colonize while simultaneously waging a total war of devaluation on the languages and cultures of the colonized." Not only does this resemble more a summary of Jean-Paul Sartre's argument in his preface to Fanon's (1991:13) book rather than that of Fanon, Jeyifo's statement also reduces the complexities of colonial discourses, policies and practices into a generalized abstraction of 'all' colonizers' imposition and devaluation, unlike Fanon's subtle discussion of the inferiority complex on the part of the colonized.

Mukoma wa Ngugi (2018: 36-9) hints at historical complexity when he notes the stress on "vernacular languages" in colonial educational policy. $\mathrm{He}$ explains that many colonized people "wanted full English immersion" and regarded fighting "for more English and less African languages in the educational system" as "a contribution to the anticolonial political struggle". Yet, he gives this remark no further thought, concludes the citations on colonial educational policy with the statement that African languages were being used "to facilitate a smoother transition to English" and continues with writing about the hegemony of racist ideologies in colonial education of which "educated Africans" became "the immediate victims". Such an interpretation would not be subscribed to by the organizers of Independent schools in Central Kenya: they did not see their stress on English in terms of victimhood but rather as a means of striving for independence.

Ngũgĩ (2018: 125) also acknowledges historical complexity when he states that, "Ironically, in some countries, the colonial period had a more progressive language policy, which ensured basic literacy in mother tongue. That was how I came to learn Gĩkũyũ." As the second vignette indicates, his evaluations of mother tongue-education as "a more "progressive language policy" would not have been shared by many colonized Kenyans, least by the organizers of Independent schools. They would rather have felt that mother-tongue education amounted to a colonial strategy of exclusion and hierarchization.

Of course, language policies in the colonial context reflected the inherently hierarchical nature of the colonial system. This, however, did not result in a uniform, homogenous linguistic situation determined by colonial rule: "colonial language policies were heterogeneous, uneven, and often self-contradictory, and ... what people actually did, linguistically, could not be encompassed by any colonial policy" (Barber 1995: 13). 
In terms of language philosophy, Ngũgĩs equation of harmony and African language on the one hand, and alienation and English on the other, is reminiscent of the stance of many missionaries in the colonial era. The German missionary linguist Dietrich Westermann, for example, wrote in 1934 that teaching English would "lead to the alienation of the individual from his own self, his past, his tradition, and his people" (cited in Peterson 2004: 121; see also: Mukoma wa Ngugi 2018: 36). In colonial thinking, such 'alienation' would only lead to 'natives' being unable to cope with 'modernity', misplaced arrogance and a threat to law and order. As Derek Peterson (2004: 120) pointed out, missionaries - and colonial officials and European settlers - were "terrified about Gikuyu who learned English".

The organizers of Independent schools who wanted English taught in the first years of primary education neither had their minds colonized nor were they wearing white masks (Fanon 1986). We cannot reduce their actions to mimicry or to subversion (Bhabha 1994). Through their stress on English, they "claimed a place for themselves within the British linguistic and political world. They contracted with colonialism, turning their English rulers into bargaining partners" (Peterson 2004: 155). This, rather than any theory of simulation, explains why missionaries were so terrified: education in English in the end challenged colonial structures.

The organizers of Independent schools would, in turn, probably have abhorred Ngũgĩ's writing of proper names - 'Njeethiberi' instead of 'Jezebel', and 'Herina' instead of 'Helen'. They insisted on writing English names "the way Englishmen spell them" (Ngũgĩ and Ngũgĩ 198o; Peterson 2004: 146, 224). Their insistence was no sign of their lack of patriotism: as indicated, they strove for wiathi, a Gikuyu concept of self-mastery often translated as 'independence', and which the organizers of Independent schools described as "doing one's work without someone lording over him" (constitution of the Kikuyu Independent School Association, cited in Peterson 2004: 143).

\section{3 Pragmatics and Linguistic Purity: The Views of Gakaara wa Wanjaũ}

In Decolonising the mind, Ngũgĩ wa Thiong'o singles out one Kenyan author in particular whose "faith in the possibilities of Kenya's national languages" had never been broken. He assesses Gakaara wa Wanjaũ as a writer "thrown up by the mass political movements of an awakened peasantry and working class" and maintains that Gakaara's "inspiration came from the mass anticolonial movement of Kenyan people, particularly the militant wing" (Ngũgĩ 
1986: 24). For Ngũgĩ, Gakaara's very act of writing in Gikuyu constituted a form of resistance.

Ngũgĩ had good reason to reflect on Gakaara's life. While Ngũgî's conversion (Gikandi 1992) dates from the end of the 196os, Gakaara had already started writing in Gikuyu in the 1940s, had changed his name from Jonah Johanna Gakaara to Gakaara wa Wanjaũ in 1952, became ambivalent about Christianity during the Mau Mau period (Pugliese 1995: 140), had been detained for eight years during the emergency - though not as Ngũgĩ (1986: 24) suggests "because of his writing in Gîkũyũ" - and Ngũgĩ took to using Gakaara's (1991) Gikuyu spelling conventions for writing his novels (Peterson 2014: 233).

Yet, Ngũgĩ's enlistment of Gakaara into the ranks of radical Marxist thinking is inappropriate (Pugliese 1994: 181-4). Gakaara had never been the radical Ngũgĩ wanted to make of him. For one, Gakaara never viewed his decision to write in Gikuyu as having anything to do with resistance. He had always made his language choices according to the audiences he had in mind. Thus, he said he wrote in Gikuyu because "I write only stories or I only deal with subjects concerning the Gîkũyũ," he wrote a pamphlet in Swahili when he wanted to reach the colonial settlers (Pugliese 1995: 139, 147), and knew full well that English was needed to reach and/or impress camp officials, the governor or queen (Gakaara 1983: 30, 34-5, 43, 53, [1988: 38, 42, 65]). Of course, such pragmatics preclude neither critical writing nor arriving at alternative forms or reaching new audiences, but Gakaara himself did not view his writing in Gikuyu as an act of resistance and also, for example, used Gikuyu in his anti-Mau Mau writing while in detention.

For Ngũgĩ, the choice was a dichotomous one - either imperial Europhone English or unifying, popular, subversive Gikuyu. Gakaara, however, reflected on the far messier linguistic realities of colonial and postcolonial Kenya. In Ũgwati wa Mũthũngũ Mũirũ, he warns of the danger/disadvantage of a black European: a person who suffers from the disease of "mixing" languages and has a "colonial rooster" in his brain (Gakaara 1974: 3, 19). Even after colonialism, this "slave chain" remained in existence, leading to devaluation and the next to disappearance of Gikuyu customs and beliefs (Gakaara 1974: 7, 15). As it amounted to "marrying a colonialist without any bride-price payment", the "colonial rooster" could in the end result in complete language loss (Gakaara 1974: 12-13).

It was not the use of English per se that Gakaara warned against in his booklet. He had never been against employing English when necessary. In his diary (Gakaara 1983), he frequently insists on the importance of knowing English and throughout the text uses English words and phrases. In 1956 - while still in detention - he urged his wife to learn English: "Get one educated woman 
to teach you English," he told her (cited in Peterson 2014: 230). In the 1989 introduction to his three-language textbook Mwalimu wa lugha tatu pamoja (Gakaara 2006: Reel 4C), he wrote: "It is advisable for a learner to put more effort in learning Kiswahili and English because both languages are widely used in schools, offices and large organizations throughout Kenya."

Even in the booklet Ũgwati wa Mũthũngũ Mũirũ (1974: 11) itself he holds that: "All the same, we do not deny that English is one of the most important languages in the world. Because of this it makes many people in Kenya and in the nations of the world mutually understand each other, and that is why it is learned so much." It is important to note that in this passage, Gakaara uses the term Kĩnngeretha (based on the word 'English'), while in the rest of the book he employs the word Gĩthũngũ (a difference that is glossed over in the only translation of the essay (Pugliese 1994: 231-42)).

What was it then that Gakaara was worried about? Gĩthũngũ, from the Gikuyu word mũthũngũ used to denote a European with, was not quite English nor was it Gikuyu. Or it was both. Derek Peterson (2004: 25) described it as "a hybrid language that was at once Gikuyu and English." In line with the general colonial anxiety over hybridity (Young 1995), missionaries disliked Gĩthũngũ, as it might play "ducks and drakes with our beautifully logical rules of spelling," one missionary commented (Peterson 2004: 133: citing Barlow 1938).

The boundaries between Gĩthũngũ and Kî̃ngeretha were difficult to draw: where did Gĩthũngũ stop and Kĩ̃ngeretha start? Sometimes the term Gĩthũngũ is used to refer to English, and that was precisely the aim. "By making Gikuyu look like English, readers also made the Gikuyu look like the English, entitled respect from the British government" (Peterson 2004: 118). Gakaara objected to such Anglicization of his mother tongue and designed an orthography of "Gĩ̃gîkũyũ karing'a": "real, true, correct" Gikuyu (Gakaara 1991; Peterson 2004: 134, 223-5).

Unlike Ngũgĩ, however, the problem for Gakaara was not with English as an imperial or Europhone language. His was a concern for linguistic purity. A "real, true" Gikuyu ought not to mix languages. Why would spouses greet each other with Harũ ndari ("Hello darling”) or Maĩ ndia ("My dear") instead of a polite Nyina wa or Ithe wa ("Mother of" or "Father of"). Would a son not forget his real Gikuyu name if he were consistently called Mbooi wa ndandi ("Daddy's boy"), Gakaara (1974: 4) wondered. Because of Gĩthũngũ, children no longer knew the proper greetings and the right kinship terminology. Why would Gikuyu use Gĩthũngũ if no speakers of other languages were around? Why could children in school not be taught in Gikuyu if all those present were Gikuyu speakers? Gakaara (1974: 7) portrayed Gĩthũngũ as negatively as he could: it was the language of boasting as people tried to impress others with their importance or 
high education; it was used by drunkards who would swear: Ndem'buu! (Damn you!) in bars.

Gakaara (1974: 7; correspondence quoted in Peterson 2014: 233) held that knowledge of culture and history could only start properly with knowing how to "read and write correctly" in one's own language, and he insisted that Gikuyu had "grammar, vocabulary, just like English" (Pugliese 1995: 149; interview with Gakaara). He called for Gikuyu to be treated on a par with English: his argument was all about respect. As Gakaara (Pugliese 1995: 78; translated from Gikuyu na Mumbi 1978: n. 11) put it:

When Gikuyu na Mumbi [the monthly magazine Gakaara published between 1976 and 1985] was started one year ago, some people thought that it was not important because it is in Gikuyu. And they went even further and said that the Gikuyu language is not loved and a magazine in Gikuyu would not work. ... We have been very pleased to see that the Gikuyu have supported us happily, thus showing respect for our language.

\section{Conclusions}

Ngũgĩ may have viewed Gakaara as a comrade-in-arms, but the latter's stance was much closer to that of the organizers of the Independent schools of the 1920 and 193os, for whom the same term "real, true" (karing'a) was used, and who insisted on correct English, as did Gakaara on correct Gikuyu. Ngũgĩ (2018: 126, 131), whose views attracted international attention, rallies against "a Europhone modernity of monolingualism". He favours "securing African languages" as "part of a whole vision of Africans securing our resources"; for him, the choice of Gikuyu is about resistance and ituĩka, which Ngũgĩ used in the sense of "revolution". For Gakaara, whose views - if noted at all - have been equated with those of Ngũgĩ, decolonization did not mean writing in Gikuyu as such (although he was the Gikuyu author par excellence). It meant speaking and writing correctly in whatever language. His linguistic project boils down to respecting the Gikuyu language, history and culture. The organizers of the Independent schools in the 1920 and 1930s equated learning correct English with striving for self-mastery and agency.

Postcolonial theory and world literature analyses often gloss over the complex histories of educational and language policy in the colonies and deny the conflicts over English and African languages. Reducing English to one thing - an imperial Europhone language - and African languages to another a unified pool of popular subversive forces - results in a denial of the histories 
of linguistic innovation, the debates and conflicts over language at more local levels, and of past imaginings of linguistic futures (Barber 1995; Marzagora 2015; Peterson 2004: 222). In any case, the language debate and thinking about independence did not start with the Makerere conference, Franz Fanon or Obi Wali: in the case of Central Kenya, the debates over colonial language, English, mixed language, and 'real, true' Gikuyu started in the 1920s at the latest.

In this contribution, the focus is not so much on language history and linguistic development as such, but rather on language ideologies and imagined linguistic futures in their relation to the political. In these imaginings, language is presented as a unified whole, correctness an ideal for which to strive, and mixing - especially for Gakaara - a sign of lack of pride. Yet, clearly Gikuyu meant more than one thing in these debates; not only English should be pluralized into Englishes; we also have to pay attention to different Gikuyus, Igbos, Zulus, Arabics, and so on. Scholars studying language-in-use are ever more urging us to abandon the concept of language as a bounded unity, instead thinking of "repertoires as lived and living experience" (Lüpke and Storch 2013: 345-59). Debates on the language of African literatures stand to gain from these sociolinguistic insights.

While postcolonial linguistic hierarchies may be part of the colonial legacy, they cannot be seen in terms of direct continuity: for that, linguistic innovation and evaluation have been too dynamic. Not only did educational policies change after decolonization, but also one can hardly directly connect the status and uses of other than colonial languages, such as American English and Mandarin, to the colonial period.

I started this chapter by referring to some recent linguistic choices on the African continent. It remains to be seen whether these can be viewed as a sign of postcolonialism, even decolonialism, or, rather stand related to a process of recolonization. In this context, new evaluations of language may come into existence and new linguistic futures may be imagined. For a way out of the dead end, for a decolonized future, part of the process may precisely be to acknowledge the messiness and particularities of historical power relations, and carefully weigh the divergent voices on decolonization and independence, taking them seriously in their own right.

\section{Acknowledgements}

While taking full responsibility for the text, I would like to gratefully acknowledge the input of Stef Craps and the participants in the BAAHE conference of December 2019, Margot Luyckfasseel, Michael Meeuwis, the anonymous reviewers and the editors of this volume. 


\section{References}

Achebe, C. 1965. "English and the African writer." Transition, 18, 75/76: 27-30.

Achebe, C. 2009. The education of a British protected child:Essays. New York: Doubleday.

Adejunmobi, M. 1999. "Routes: Language and the identity of African literature." Journal of Modern African Studies, 37, 4: 581-596.

Barber, K. 1995. "African language literature and postcolonial criticism." Research in African Literatures, 26, 4: 3-30.

Barber, K. and G. Furniss. 2006. "African language writing." Research in African Literatures, 37, 3: 1-14.

Bhabha, H. K. 1994. The location of culture. London: Routledge.

Fanon, F. 1986 [French edition: 1952]. Black skin, white masks. London: Pluto.

Fanon, F. 1991 [French edition: 1961]. The wretched of the Earth. New York: Evergreen.

Gakaara wa Wanjaũ. 1974 [first edition unknown, probably 1971]. Ũgwati wa Mũthũngũ Mũirũ. Karatina: Gakaara Press.

Gakaara wa Wanjaũ. 1983. Mwandĩki wa Mau Mau ithaamĩrio-inĩ [translated as Mau Mau author in detention (1988)]. Nairobi: Heinemann.

Gakaara wa Wanjaũ. 1991. Mwandĩkĩre wa Gĩ̃gĩkũyũ Karĩng'a [True, real, proper Gikuyu writing]. Karatina: Gakaara Press.

Gakaara wa Wanjaũ. 2006. "The papers of Gakaara wa Wanjaũ”, collected by K. Njogu, D. Woodson, A. Biersteker and D. Peterson, 6 microfilm reels. New Haven: Yale University Library. Consulted with the courtesy of African Studies Centre of Cambridge University Library.

Gikandi, S. 1992. "Ngugi's conversion: Writing and the politics of language." Research in African Literatures, 23, 1: 131-144.

Jeyifo, B. 2018. "English is an African language - Ka Dupe! [for and against Ngũgĩ]." Journal of African Cultural Studies, 30, 2: 133-147.

Lo Liyong, T. 1969. The last word. Nairobi: East African Publishing House.

Lüpke, F. and A. Storch. 2013. Repertoires and choices in African languages. Boston: De Gruyter Mouton.

Marzagora, S. 2015. "Literatures in African languages." Journal of African Cultural Studies, 27, 1:1-6. (Introduction to JACs special issue on African-language literature.)

Mukoma wa Ngugi. 2018. The rise of the African novel. Politics of language, identity and ownership. Ann Arbor: University of Michigan Press.

Ngũgĩ wa Thiong'o. 1986. Decolonising the mind. Harare: Zimbabwe Publishing House.

Ngũgĩ wa Thiong'o. 2007. Mũrogi wa Kagogo. Mbuku ya Mbere na ya Kerĩ. Nairobi: East African Educational Publishers (first part published 2004). [English translation: 2007. Wizard of the crow. New York: Anchor Books].

Ngũgĩ wa Thiong'o. 2018. "The politics of translation: Notes towards an African language policy." Journal of African Cultural Studies, 30, 2: 124-132. 
Ngũgĩ wa Thiong’o and Ngũgĩ wa Mĩriĩ. 198o Ngaahika ndeenda. Nairobi: East African Educational Publishers.

Northrup, D. 2013. How English became the global language. New York: Palgrave MacMillan.

Peterson, D. R. 2004. Creative writing. Translation, bookkeeping, and the work of imagination in colonial Kenya. Portsmouth: Heinemann.

Peterson, D. R. 2014. "Ethnography and cultural innovation in Mau Mau Detention Camps: Gakaara wa Wanjaũ’s Mĩhĩrĩa ya Agĩkũyũ." In Ten books that shaped the British Empire, edited by I. Hofmeyr and A. Burton, 216-237. Durham: Duke University Press.

Plonski, P., A. Teffera and R. Brady. 2013. "Why are more African countries adopting English as an official Language." ASA conference paper, 23 November. https://www. booksforafrica.org/assets/documents/2013-ASA-Conference---English-Languagein-Africa-PAPER.pdf.

Pugliese, C. 1994. "The organic vernacular intellectual in Kenya: Gakaara wa Wanjau." Research in African Literatures, 25, 4: 177-187.

Pugliese, C. 1995. Author, publisher and Gikuyu nationalist. The life and writings of Gakaara wa Wanjau. Bayreuth/Nairobi: Bayreuth African Studies/IF RA.

Roberts, A. (Ed.). 1990. The colonial moment in Africa. Essays on the movement of minds and materials,1900-1940. Cambridge: Cambridge University Press.

Soussi, H. 2020. "World Englishes in multilingual Morocco." World Englishes, 1-9. DoI: 10.1111/weng.12512.

Wali, O. 1963. "The dead end of African literature?" Transition, 10: 13-16.

Wheeler, A. 2013. "Cultural diplomacy, language planning, and the case of the University of Nairobi Confucius Institute." Journal of Asian and African Studies, 49, 1: 49-63.

Young, R. 1995. Colonial desire: Hybridity in theory, culture, and race. New York: Routledge. 